\title{
Retraction Note: Coastal atmospheric climate based on remote sensing images and corporate Weibo brand marketing
}

\author{
Xiaoxi $\mathrm{Du}^{1}$
}

Published online: 11 November 2021

C) Saudi Society for Geosciences 2021

Retraction Note: Arabian Journal of Geosciences (2021) 14: 974 https://doi.org/10.1007/s12517-021-07343-5

The Editor-in-Chief and the Publisher have retracted this article because the content of this article is nonsensical. The peer review process was not carried out in accordance with the Publisher's peer review policy. The author has not responded to correspondence regarding this retraction.

The original article can be found online at https://doi.org/10.1007/ s12517-021-07343-5.

Xiaoxi Du

cicihuel@163.com

1 School of E-commerce and Logistics Management, Henan

University of Economics and Law, Zhengzhou, Henan,

China 